TILTAI, 2016, 1, 53-61, ISSN 1392-3137 (Print), ISSN 2351-6569 (Online)

\title{
GEROS MOKYKLOS KONCEPCIJA: SAMPRATOS NARATYVAS
}

\author{
Vilija Targamadzè \\ Vilniaus universitetas
}

\begin{abstract}
Anotacija
Bendrojo ugdymo mokykla išgyvena sudètingą laikotarpị - 2015 m. priimta Geros mokyklos koncepcija, kurią mokyklai dera ịgyvendinti. Tačiau tai ne taip paprasta, nes reikia keisti mokyklos veiklos atramos taškus, orientyrus, modeliuoti jos veiklą, kuri turètų atitikti minètą koncepciją. Vienas galimų kliuvinių gali būti Geros mokyklos koncepcijos supratimas. Todèl 2016 m. atliktas empirinis kokybinis tyrimas, siekiant išsiaiškinti šios koncepcijos akcentus, kaip ją supranta ekspertai ir kokie yra jų akcentai. Paaiškejjo, kad ekspertų geros mokyklos samprata iš esmès atitinka Geros mokyklos koncepcijos turinio lauką. Tik ekspertai neakcentuoja vertybinio aspekto. Tai yra signalas susirūpinti pamatiniais vertybiniais ugdymo mokykloje dalykais, juos išsiaiškinti ir veiklą mokykloje konstruoti vertybiniu pagrindu. Be to, dera mokyklos veiklos kryptis reflektuoti ir jas modeliuoti, remiantis Geros mokyklos koncepcija, kaip veiklos žemėlapiu.
\end{abstract}

PAGRINDINIAI ŽODŽIAI: gera mokykla, samprata, ekspertinis vertinimas.

\begin{abstract}
A comprehensive school lives through a challenging period - the Good School Conception, which the school should implement, was approved. However, this is not so easy because it is necessary to change reference points and landmarks of school activity, to model its activity by conforming the Good School Conception. Perception of the Good School Conception might be one of the possible hindrances. Thus in 2016 the empirical qualitative survey, during which it was tried to find out aspects of the Good School Conception and the perception of its experts as well as their accents, was performed. It has become evident that the Good School Conception by the experts basically conforms the content field of the Good School Conception. But the experts do not emphasize the value aspect. This is the signal to concern about fundamental value matters in the school, to find them out and to construct the activity in the school on value fundamental. In addition, the direction of school activity should be reflected and modelled by referring to the Good School Conception as activity map.

KEY WORDS: Good School, notion, qualitative evolution.
\end{abstract}

DOI: http://dx.doi.org/10.15181/tbb.v74i2.1366

\section{Ivadas}

Bendrojo ugdymo mokykla - svarbi švietimo sistemos sudètinė dalis. Joje ilgiau ar trumpiau mokèsi ar mokosi beveik visi visuomenès nariai. Taigi ji neišvengiamai turi poveiki jų asmenybės formavimui(-si), visam sociumui. Mokyklos reikšmę sociume būtų sunku pervertinti, bet šiandien bendrojo ugdymo mokyklos veikla nèra veiksminga - tai liudija ir Nacionalinio mokinių mokymosi pasiekimų tyrimų rezultatai. 2014 metų išvadose rašoma: „Ne visos pastaruoju metu pradiniame ir pagrindiniame ugdyme diegtos naujovés pasiekė savo tikslą. Pavyzdžiui, 
tyrimo rezultatai leidžia kelti hipotezę, kad dalies parengtų ugdymo kokybės gerinimo rekomendacijų pedagogai nesuprato arba jos buvo ne visai teisingos. Yra pagrindo manyti, kad dalis naujovių dažnai yra tik imituojamos, bet ne nuosekliai ir tikslingai diegiamos“ (NEC, 2015).

Todèl neatsitiktinai ieškoma ịvairesnių bendrojo ugdymo modelių (jau yra ịsikūrusios Montessori, Valdorfo, katalikiškos mokyklos ir pan.). Naujosios mokyklos savo veiklą grindžia savitais ugdymo modeliais, kurie atitinka LR įstatymus. 2015 m. gruodžio 21 d. patvirtinta Geros mokyklos koncepcija. Tad kaip suprantama gera mokykla? Šis klausimas aktualus, nes neaišku, ar bus adekvačiai suprasta reformos architektų mintis, ar jos igyvendinimas nebus imituojamas. Kyla klausimai: kokia geros mokyklos samprata vadovaujasi mokyklų vadovai, tèvai, nacionalinio lygmens politikos igyvendintojai ir pan.? Ar ji sutampa su samprata, kuri pateikta Geros mokyklos koncepcijoje?

Šioje samprotavimų erdveje formuluojamas mokslinès problemos klausimas: ar mokyklų vadovų, pedagogų, tėvų samprata atitinka Geros mokyklos koncepcijoje (2015) suformuluotą geros mokyklos sampratą? Jei ne, tai kuo jos skiriasi?

Straipsnio tikslas: išryškinti Geros mokyklos koncepcijos ir geros mokyklos sampratos akcentus ekspertų požiūriu.

Tyrimo objektas - geros mokyklos sampratos akcentai.

Metodai: mokslinès literatūros, dokumentų analizè, ekspertinè apklausa.

Šiame straipsnyje išryškinami koncepcijoje nurodyti ir ekspertų įsivaizduojami geros mokyklos panašumai bei skirtumai. Juos įvertinus, galima būtų optimizuoti geros mokyklos kūrimą. Šis aspektas Lietuvoje dar netirtas, tad išryškèja tyrimo naujumo, praktinio reikšmingumo ryšys.

Straipsnyje remiamasi socialinio rekonstruktyvizmo metodologine prieiga: žmonès apie objektą konstruoja savo asmenini supratimą, tai nėra jiems perduotų žinių ar gebėjimų veidrodinis atspindys, o jų asmeninè refleksija (Kukla, 2000).

\section{Geros mokyklos samprata teoriniu požiūriu}

Geros mokyklos koncepcijoje (2015) apibrěžta jos samprata. Ją detalizuoti gali padèti schema „Geros mokyklos veiklos aspektai ir jų ryšiai“ (Ruškus, Jonynienè, Želvys, Bacys, Simonaitienè, Murauskas, Targamadzè, 2013) (žr. 1 pav.).

Šiame paveiksle aiškiai išskirtos dvi dalys: mokyklos misija ir jos igyvendinimą lemiantys veiksniai. Atkreiptinas dėmesys, kad, ,siuo metu, visuomenei vertinant mokyklą, yra ịprasta pagrindiniais jų gerumo rodikliais laikyti formalius akademinius - egzaminų, testų - rezultatus“ (Geros mokyklos koncepcija, 2015, 
p. 2), o Geros mokyklos koncepcijoje ugdymo rezultatą sudaro trys dėmenys: asmenybės branda, pasiekimai ir pažanga. Be to, sureikšminamas vaiko mokyklinis gyvenimas ir jo ugdymasis, akcentuojant mokymąsi. Taigi pedagoginè veikla akivaizdžiai nukreipiama ị mokymosi paradigmą. Parodant misijos įgyvendinimui ittaką darančius veiksnius, akcentuojama ugdymo aplinkos ir ugdymo (mokymo) sąveika bei jai reikšmingi veiksniai: darbuotojai, visos mokyklos bendruomenès, kaip besimokančios organizacijos, gyvavimas, lyderystės ir vadybos reikšmė. Paryškinamas ir mokyklos bei vietos bendruomenès steigejjo bendradarbiavimas.

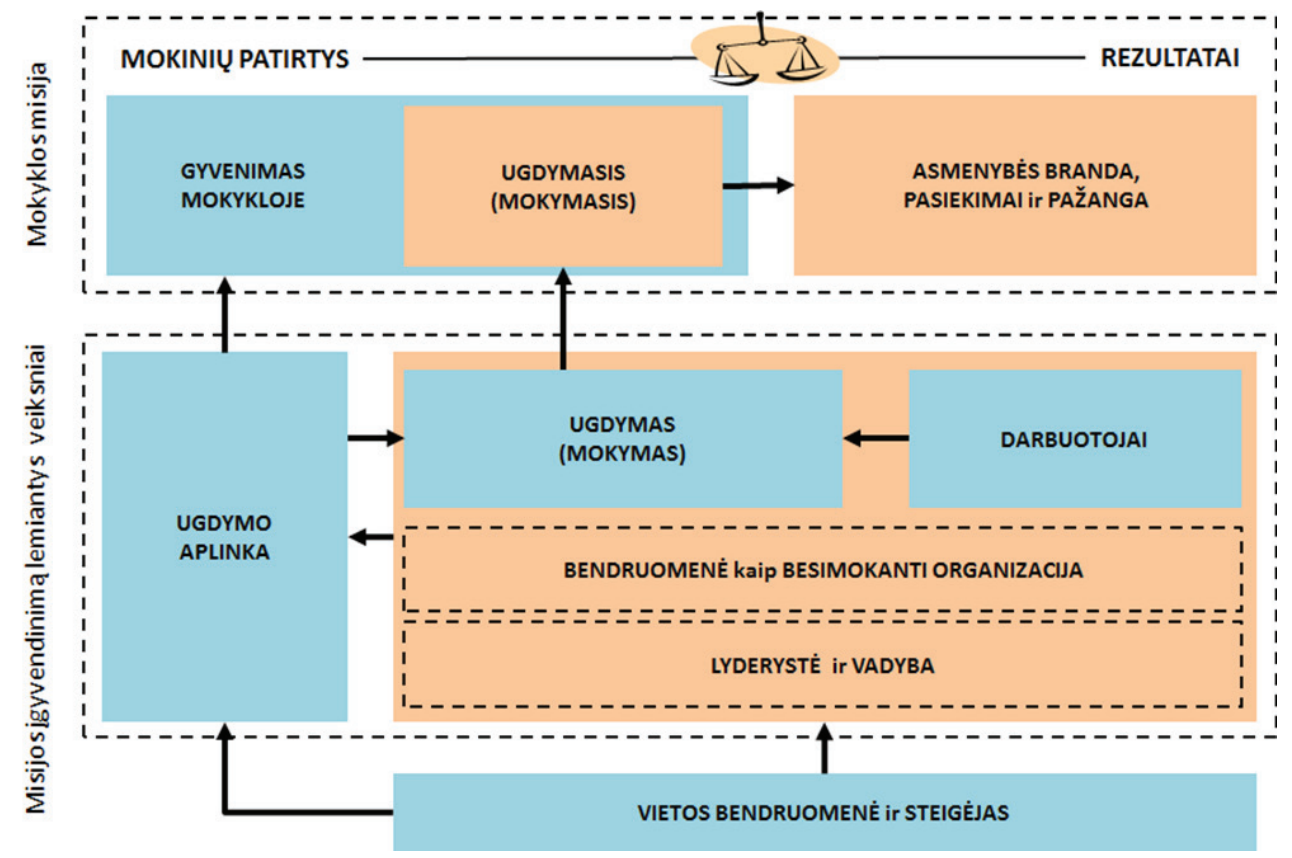

1 pav. Geros mokyklos veiklos aspektai ir jų ryšiai

(Geros mokyklos koncepcija, 2013, p. 4)

Geros mokyklos koncepcijos analizė leidžia teigti, kad jos gyvybingumą kurti turi mokyklos bendruomenès nariai, paritetiniais pagrindais bendradarbiaudami su vietos bendruomene ir steigeju. Šis kūrybinis bendradarbiavimas - tai savos mokyklos projekto modeliavimo ir jos igyvendinimo bei tobulinimo procesas, igyvendinant mokyklos misiją, t. y. ji turi tapti ,pamatinėmis humanistinėmis vertybėmis ugdymą grindžianti, prasmès, atradimų ir asmens ugdymo(si) sẻkmès siekianti mokykla, kuri savo veikloje vadovaujasi mokyklos bendruomenès susitarimais ir mokymusi“ (Geros mokyklos koncepcija, 2015, p. 1). 


\section{Geros mokyklos samprata ekspertų požiūriu}

Anksčiau aptartas teorinis konceptas. İdomu, kaip gerą mokyklą ịsivaizduoja ekspertai. Kokie yra sąlyčio taškai ir kokios skirtys. Tuo tikslu 2016 m. sausio kovo ménesiais atliktas kokybinis tyrimas, kuris vyko dviem etapais. Pirmame etape pasirinkta 10 ekspertų: iš dviejų Lietuvoje veikiančių tẻvų organizacijų (Lietuvos tẻvų forumo ir Nacionalinès šeimų ir tèvų asociacijos) po vieną ekspertą, du ekspertai pasirinkti iš nacionalinio lygmens švietimo politiką igyvendinančių institucijų, du ekspertai atstovavo bendrojo ugdymo mokykloms, kuriose mokoma ne lietuvių kalba, ir po du atstovus buvo iš bendrojo ugdymo mokyklų lietuvių mokomąja kalba bei iš katalikiškų mokyklų. Be to, vienas iš ekspertų (išskyrus mokyklas) buvo edukologijos mokslų daktaras ir vienas iš ekspertų dalyvavęs rengiant Geros mokyklos koncepcija arba jos igyvendinimo dokumentą. Mokykloms atstovavo vadovai, turintys ne mažesnę nei trejų metų vadovavimo patirtị ir rengę savo mokyklos sampratą. Ekspertai atsake ị dvylika parengto klausimyno pozicijų. Šio tyrimo tikslas buvo išsiaiškinti, kaip jie supranta gera mokykla, kokias mato jos igyvendinimo galimybes ir trikdžius. Tyrimo objektas - geros mokyklos samprata ir jos ịgyvendinimas ekspertų nuomone. Metodas - ekspertiné apklausa raštu. Tyrimas vyko 2016 sausio - vasario (iki antros dekados pabaigos) mènesiais.

Kitas etapas prasidejjo $2016 \mathrm{~m}$. vasario trečią dekadą ir baigèsi kovo mènesį. Dalyvavo penki mokyklų vadovai, turintys ne mažiau kaip trejų metų vadovavimo mokyklai patirtị ir nerašę mokyklos sampratos. Trys buvo iš miestų ir du - iš kaimiškųų vietovių, atitinkamai - gimnazijų ir pagrindinių mokyklų, progimnazijų vadovai. Šio tyrimo etapo tikslas - ,pasitikslinti geros mokyklos sampratą mokyklos vadovų požiūriu“, tyrimo objektas - ,geros mokyklos samprata mokyklos vadovų požiūriu“. Metodas - ekspertinè apklausa raštu, remiantis ankstesniu klausimynu, jị papildant klausimu, „kaip Jūs suprantate, kas yra gera mokykla?“

Šiame straipsnyje atkreipiamas dėmesys ị ekspertų geros mokyklos sampratą, išryškinant jos akcentus. Be abejo, kiekvienas ekspertas akcentavo skirtingus mokyklos aspektus, susijusius su mokyklos samprata. Pavyzdžiui, vienas ekspertas - mokyklos vadovas - teigè, kad mokykloje reikia ,plètoti prigimtines žmogaus galias, sudaryti sąlygas kiekvienam mokiniui augti, mokytis, tobulèti, ugdytis saugioje aplinkoje ir ugdyti kompetencijas, reikalingas sėkmingai socialinei integracijai ir mokymuisi visą gyvenimą. Arba, kaip teigia profesorius Š. Amonašvilis, ,,ugdymo proceso šerdis: tobulinti ir auklėti vaiko gyvenimą pačiu gyvenimu“. Kitas nurodo, kad dera ,paruošti vaiką laimingam gyvenimui (gebejjimas prisitaikyti labai greitai besikeičiančiame pasaulyje, savo vietos atradimas, išmokimas valdyti save)“. Jau šių dviejų mokyklų vadovų geros mokyklos samprata yra skirtinga: pirmuoju atveju labiau paryškinama mokyklos atsakomybė (ji turi sudaryti sąlygas vaiko 
saviugdai, kurti saugią aplinką ir pan.), kitoje orientuojamasi ị ugdymo(-si) rezultatą. Ir nors pirmoje ir antroje sampratose nurodytas ugdymo(-si) rezultatas, mokyklos bendruomenès aspektas neišaiškejja. $\mathrm{O}$ ir mokinio ugdymo(-si) rezultatas kitaip atrodo: ,ugdyti kompetencijas, reikalingas sẻkmingai socialinei integracijai ir mokymuisi visą gyvenimą “ ir „paruošti vaiką laimingam gyvenimui“. Abu ekspertai tarsi labiau modeliuoja rezultatą iš mokyklos perspektyvos, neakcentuodami ugdomosios sąveikos, nepakankamas dèmesys skiriamas mokinio saviugdai, jo siekiniams ir pan. Šiuos misijos apibrèžimus palyginkime su Geros mokyklos koncepcijoje (2015) nurodomais siekiniais. Pavyzdžiui: „Pagrindiniai ir pageidaujami mokyklos veiklos rezultatai - mokinių asmenybès branda, individualias galimybes atitinkantys ugdymo(si) pasiekimai ir nuolatinė ugdymo(si) pažanga. Mokiniai suvokia save kaip asmenybes, džiaugiasi savo pasiekimais ir kantriai ivveikia nesėkmes, neprarasdami tikèjimo, kad jiems pavyks. Jie priima naujus iššūkius kaip kelią į tobulèjimą, sveikai pasitiki savo jègomis, tačiau adekvačiai ir kritiškai vertina realybę“" (Geros mokyklos koncepcija, 2015, p. 3). Kaip matome, išryškejja, kad koncepcijoje labiau akcentuojama mokinio asmenybė, jo saviugda, augimas etc., o ne mokyklos vaidmuo. Ryškejja skirtingos konstruktų pozicijos anksčiau minèti ekspertai konstrukto atskaitos tašku pasirenka mokyklos poziciją ir mato savo ugdymo rezultatą, o koncepcijoje atskaitos taškas yra vaikas, jo ūgis, sąveika ugdomojoje aplinkoje, bendruomenèje etc.

Iš esmès ekspertų mokyklos vadovų atskaitos pozicija yra labiau organizacijos ar net ir mokyklos vadovų ar vadovo: „Mokyklos misija - telkiant mokyklos bendruomenès lyderius bei remiantis bendruomenès susitarimais kurti savita kultūra grịstą ugdymo sistemą, užtikrinančią brandžios asmenybès ugdymą"; , geros mokyklos misija - siekti visų mokinių pažangos, skatinti visų mokyklos bendruomenès narių tobulejimą, kurti atvirą mokyklą, kurioje visiems būtų gera“; „sudaryti sąlygas kiekvienam mokiniui igyti mokymosi ir gyvenimo patirtị bei žinias mokykloje, bendradarbiaujant su mokytojais ir kitais ugdymo veikejais, kurie kartu su visa mokyklos bendruomene ,išranda“ mokyklą. Tokia būtų geros mokyklos (kaip ugdymo ịstaigos) misija“. Taigi Geros mokyklos koncepcijos ir praktikų atskaitos taškas skiriasi ir tai galima suprasti, nes vadovai modeliuoja savo veiklą ir pateikia savo sampratos ižžalgas. Pažymètina, kad tiek ekspertų, tiek koncepcijos autorių pateikiamas požiūris ị vaiką daugiau ar mažiau kaip ugdymo(-si) subjektą - minima ugdomoji aplinka, sąlygų sudarymas vaiko ugdymuisi ir panašiai.

Palyginę ne mokyklos vadovų ekspertų atsakymus, rasime daugiau diversifikacijos: vieni labiau akcentuoja mokyklą (,geros mokyklos misija - kurti prasmès, atradimų ir mokymosi sẻkmės erdvę“; ,,mokyklos misija - tai sąlygų sudarymas, kur besimokantysis mokosi tapti. Tapsmo vieta"), kiti daugiau dèmesio kreipia $\underset{i}{ }$ ugdytini (,geros mokyklos misija - atsižvelgiant ị konkrečios mokyklos tipo ir 
bendruomenès poreikius, igyvendinti ugdymo tikslus siekiant kiekvieno jos nario tobulejimo ir bendradarbiavimo. Svarbiausiais tikslas - kiekvieno ugdytinio individuali pažanga ir ugdymosi rezultatai, kurie būtų prasmingi pačiam ugdytiniui, jo tèvams (globejjams) ir padèsiantys toliau mokytis, ịsitvirtinti gyvenime ir visuomenëje“; ,ugdytinio visaverčio ugdymosi vieta, siekiant ugdymo(-si) tikslų igyvendinimo").

Visgi ekspertų pozicijose pasigendama vertybinio atskaitos taško: Geros mokyklos koncepcijoje akcentuojamas ugdymo grindimas pamatinėmis humanistinèmis vertybėmis, tuo tarpu ekspertai šio atskaitos taško nepabrèžia. O ugdymo vertybinis pamatas svarbus, nes tai turi susisieti su ugdymo filosofija, kultūra, mokyklos filosofija. Kiekvieno iš jų pagrindas yra vertybès. Jos turi būti susijusios, nes, jei ugdymas bus grindžiamas viena filosofija, o mokyklos filosofija ar kultūra nederès, nes turèsime vertybių eklektiką, kuri gali tapti mokyklinio gyvenimo destrukcijos akstinu.

Tiek ekspertų, tiek Geros mokyklos koncepcijoje pabrèžiama vaiko prasmės paieška ir atradimas. Tiesa, ši aspektą labiau akcentuoja tèvai: „Geros mokyklos misija - kurti prasmès, atradimų ir mokymosi sẻkmès erdvę“; ,svarbiausia yra asmeninė ūgtis tikrojo savojo AŠ paieškose. Bendrabūvyje turètume vienas kitam padèti siekti asmeninio tobulèjimo". Antrasis ekspertas tiesiogiai vaiko prasmingos veiklos neịvardino, tačiau asmeninè ūgtis ieškant savojo Aš tiesiogiai koreliuoja su asmenybės prasme ir atradimais. Vaiko atradimų ir jo asmenybinis ugdymas(-is) atsiskleidžia beveik visų ekspertų atsakymuose: „Vaiko atradimų džiaugsmas ir jo tobulèjimas, mokymosi sèkmès pajautimas“; ,vaiko patirtinis mokymasis, atradimais ir sékme grịstas“, ,atradimas, sẻkmé, asmeninė patirtis ir branda" ir pan.

Bendruomenès susitarimus akcentavo kai kurie ekspertai, pavyzdžiui: „Susitarimu grịstas bendruomenès veikimas, padedantis kiekvienam asmeniškai tobulèti“; , ,besimokanti bendruomené - ypatingai svarbu apmąstyti, ką žinau, sugebu ir kokioje srityje turiu tobulèti. Nuolatinis mokymasis yra vienas iš esminių šiandienos globalios visuomenès poreikių“; „mokyklos bendruomenè bendradarbiaujanti ir besimokanti, padedanti vaikui tobuletti“ etc. Taigi vieni ekspertai akcentavo bendruomenès mokymąsi, kiti ne, tačiau atsakymų kontekste aišku, kad bendruomenè, ekspertų nuomone, yra svarbus akstinas vaiko ugdymuisi.

Apibendrinant galima teigti, kad:

Geros mokyklos koncepcijoje pateikta mokyklos samprata iš esmès atitinka ekspertų nurodytą geros mokyklos sampratą - ekspertai pabrēžia vaiko mokymosi prasmès, atradimo, mokymosi sẻkmės reikšmingumą, bendruomenès ịtaką ir svarbą vaiko ugdymesi, tai savitai pateikdami. Tačiau iš esmès mokyklos sampratoje 
ugdymo vertybinis pamatas neišryškintas, tai suponuoja mintị apie pamatinių ugdymo dalykų problemą.

Geros mokyklos samprata ekspertų suprantama kaip gairès, mokyklos žemèlapis, kurị turi sukonstruoti pati mokykla, išryškindama mokyklos siekinius ir apsibrezždama tikslus. Jų siekiui mokyklos bendruomenei reikia susikurti ugdymo politiką, kuri atitiktų bendrą ugdymo kryptị, sumodeliuotą konceptualių valstybinių švietimo dokumentų, kartu atskleidžiančią mokyklos savitumą. Tuo tikslu mokyklos bendruomenè, bendradarbiaudama su vietos bendruomene ir kitais socialiniais partneriais, turi susitarti dèl mokyklos veiklos pamato, juo grịsti mokyklos gyvenimą ir susikurti strategiją, kuri atlieptų mokyklos siekius ir bendruomenès narių lūkesčius.

Gauta 20160701

Pasirašyta spaudai 20161015

\section{Literatūra}

Geros mokyklos koncepcija. (2015). Patvirtinta Lietuvos Respublikos švietimo ir mokslo ministro $2015 \mathrm{~m}$. gruodžio 21 d. įsakymu Nr. V-1308. Prieiga internete: http://www.smm.lt/web/lt/teisesaktai/listing?date from=2015-12-08\&date_till=2016-01-01\&text=\&submit_lawacts_search (žiūrèta 20160130 ).

Kukla, A. (2000). Social Constructivism and the Philosophy of Science. New York: Routledge.

NEC. (2015). Trumpos 2014 metu Nacionalinio mokiniu mokymosi pasiekimu tyrimo išvados. Prieiga internete: http://www.nec.lt/failai/5565_Trumpos_2014_met_NMPT_isvados_SMM.pdf (žiūrèta 201603 05).

Ruškus, J., Jonynienė, V., Želvys, R., Bacys, V., Simonaitienè, B., Murauskas A., Targamadzė V. (2013). Geros mokyklos koncepcija. Prieiga internete: https://www.google.lt/?gws_rd=ssl\#q=geros+mokyklos+koncepci ja+2013 (žiūrèta 201602 13).

\section{THE GOOD SCHOOL CONCEPTION: THE NARRATIVE OF THE NOTION}

\section{Vilija Targamadzè}

\section{Summary}

When rectifying reference points of the activity of a comprehensive school, the following question arises: what is a good school? Though the Good School Conception was confirmed on December 21, 2015, this question is still urgent as the danger for its adequate understanding by reform architects and implementers, simulation of its implementation exists. 
In the space of this reasoning the following research problem question is formulated: whether the notion of school principals, teachers, and parents coheres with the good school perception formulated in the Good School Conception (2015). If not, so how they differ.

The aim of the article is to point out similarities and differences of important points in the Good School Conception and the notion of a good school considering the experts' viewpoint.

Research object is the Good School Conception in the context of its important points.

Methods: analysis of scientific literature and documents, expert survey.

The article refers to methodological approach of social re-constructivism: people construct their personal understanding round the object; this is not the specular reflection of the knowledge or abilities transferred to them, his is their personal reflection (Kukla, 2000).

This article highlights similarities and differences of formal and expert-imagined good school as well as possible obstacles for its implementing. Having assessed them, it would be possible to optimize creation of the good school.

In the article the notion of the good school presented in the Good School Conception and the obtained results of the qualitative research performed in January - March 2016 are compared. Basically the experts named main important points indicated in the Good School Conception. Undoubtedly, they present this in their original way. However, the experts' positions miss the value starting point - the Good School Conception emphasizes substantiation of education by fundamental humanistic values while the experts do not define this starting point. The value fundamental of education is important as it must relate to education philosophy, culture, school philosophy. Values make its fundamental. They have to be coherent because if education is based on one philosophy and school philosophy or culture is not in harmony, we will face eclecticism of values, which can become the impetus for destruction of school life.

In summing-up the considerations of the article it is stated:

The Good School Conception presents the school notion, which basically conforms the Good School Conception indicated by the experts: the experts point out the importance of child's learning sense, relevance of learning success, influence and importance of the community in child's development; they present this in original way. However, the school conception does not highlight the value fundamental of education; this presupposes the thought about the problem of education fundamental matters.

The Good School Conception is perceived by the experts as guidelines, school map, which the school has to construct by highlighting school objectives and 
defining its goals. In order to achieve them the school community has to create education policy that corresponds general direction of education, which is modelled in conceptual education documents of the state, and at the same time it reflects school originality. Thus the school community while collaborating with the local community and other social partners have to agree on essential issues of the school activity, to base school life on them and to create the navigation system for their implementation. 
